\title{
The Bork-Baykal Phenomenon in Congenital Melanocytic Nevus
}

\author{
Tugba Kevser Uzuncakmak, Defne Özkoca, Server Serdaroğlu
}

Istanbul University-Cerrahpasa, Cerrahpasa Medical Faculty Department of Dermatology

Key words: Baykal Phenomenon, congenital nevus, melanocytic nevus

Citation: Uzuncakmak TK, Özkoca D, Serdaroğlu S. The Bork-Baykal phenomenon in congenital melanocytic nevus. Dermatol Pract Concept. 2021;11(3): e2021058. DOI: https://doi.org/10.5826/dpc.1103a58

Accepted: December 12, 2020; Published: July 8, 2021

Copyright: $\odot 2021$ Uzuncakmak et al. This is an open-access article distributed under the terms of the Creative Commons Attribution License BY-NC-4.0, which permits unrestricted noncommercial use, distribution, and reproduction in any medium, provided the original authors and source are credited.

Funding: None.

Competing interests: The authors have no conflicts of interest to disclose.

Authorship: All authors have contributed significantly to this publication.

Corresponding author: Dr Tugba Kevser Uzuncakmak, MD, Istanbul University Cerrahpasa, Medical Faculty,Department of Dermatology, Istanbul, Turkey. Email: drtugbakevser@gmail.com

\section{Case Presentation}

A 6-month-old girl was admitted to our outpatient clinic for dermoscopic examination of a large congenital melanocytic nevus on chest (CMN). Dermatological examination revealed
$15 \times 15 \mathrm{~cm}$ sized, light-dark brown, multicomponent $\mathrm{CMN}$ with 2 excision scars over the left breast. Nipple and areola were not involved (Figure 1A). Dermoscopic examination revealed a whitish homogenous area surrounded by a brown homogenous area and dark brown, symmetrical reticular lines (Figure 1B).

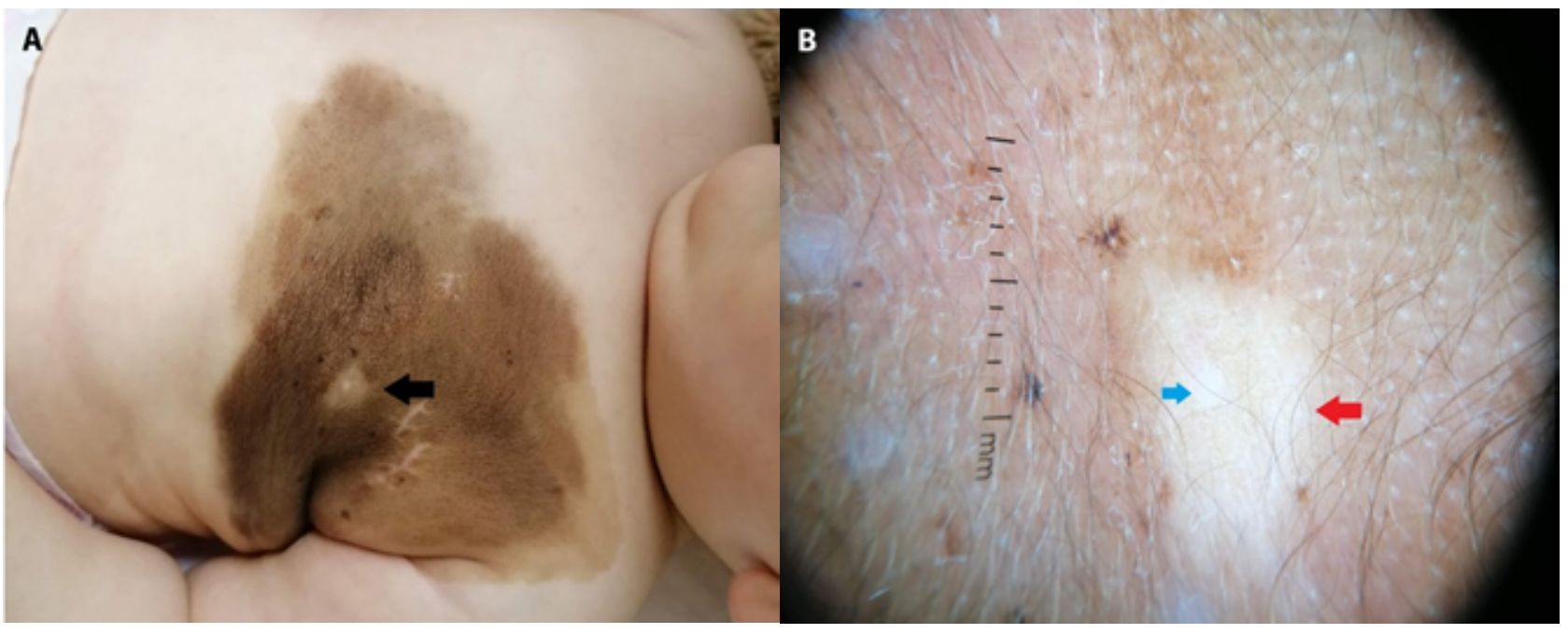

Figure 1. (A) $15 \times 15 \mathrm{~cm}$ sized, light-dark brown, multicomponent $\mathrm{CMN}$ with two excision scars over the left breast without the involvement of the nipple and areola. (B) Whitish homogeneous area surrounded by brown homogeneous area and dark brown, symmetrical reticular lines. 


\section{Teaching Point}

Sparing of the nipple-areola complex (the Bork-Baykal phenomenon) was first reported by Baykal et al in 8 cases of large congenital melanocytic nevus (CMN) sparing the areola [1]. 2 years later, Happle referred to this entity as "the BorkBaykal phenomenon: a new and rarely seen entity referring to the nipple-sparing nevus of the breast". Medium and large CMNs are a subtype of hamartomas that present at birth. Their peculiar appearance was linked to the different histopathological features and embryologic developmental periods of the affected tissues and the nipple-areola complex [2].

\section{References}

1. Baykal C, Solakoğlu S, Polat Ekinci A, Yazganoğlu KD. Large Congenital Melanocytic Nevus on the Breast Sparing the Nipple and Areola. Pediatr Dermatol. 2015; 32: 514-517. DOI: 10.1111/ pde.12610. PMID: 25940669

2. Argenziano G, Caccavale S, Brancaccio G, Moscarella E, Piccolo V, Lallas A. Reassessing the Biological Significance of Congenital Melanocytic Nevi. Dermatol Pract Concept. 2020;10(3):e2020068. DOI: 10.5826/dpc.1003a68. PMID: 32676216 